\title{
PRIMARY LEIOMYOSARCOMA OF TONGUE - A RARE NEOPLASM
}

Avani Jain ${ }^{1}$, Shashank Nath Singh ${ }^{2}$, Pawan Singhal ${ }^{3}$, Manprakash Sharma ${ }^{4}$, Sunil Samdani ${ }^{5}$

\section{HOW TO CITE THIS ARTICLE:}

Avani Jain, Shashank Nath Singh, Pawan Singhal, Manprakash Sharma, Sunil Samadni.“Primary

Leiomyosarcomaof Tongue - A Rare Neoplasm". Journal of Evolution of Medical and Dental Sciences 2014; Vol. 3, Issue 02, January 13; Page: 473-478, D0I:10.14260/jemds/2014/1852

ABSTRACT: BACKGROUND: Primary leiomyosarcoma of the tongue is an extremely rare malignant mesenchymal tumour that exhibits smooth muscle differentiation. Only 23 cases of this neoplasm have been described in the literature. CASE REPORT: This article describes a case report of a primary leiomyosarcoma of the right lateral border of the tongue in a 35-year-old male. The diagnosis was supported by histological findings and immunohistochemical positivity for desmin, vimentin and smooth muscle actin. Hemiglossectomy with supraomohyoid neck dissection was done with three years follow-up, without evidence of local recurrence or distant metastasis. The available literature has been reviewed for a better understanding of this rare neoplasm. CONCLUSION: Leiomyosarcoma in this unusual site seems to have a better prognosis than elsewhere, although the number of cases are too small to draw a conclusion. Further research with longer follow-up is required to better understand this rare pathological entity.

KEY WORDS: Leiomyosarcoma, tongue, immune histochemistry.

INTRODUCTION: Leiomyosarcoma is a rare malignant mesenchymal neoplasm arising from smooth muscles. It accounts for 6-7\% of all soft tissue sarcomas and arises mainly in the uterus, gastrointestinal tract and retroperitoneum 1 . Only 3-10\% of leiomyosarcomas arise from head and neck region; and its occurrence in the tongue, is even lower owing to the paucity of smooth muscles in the region ${ }^{2}$. There are only 23 reported cases in the literature of primary leiomyosarcoma arising from the tongue ${ }^{2-21}$. This article describes an additional case of primary leiomyosarcoma of the tongue, its immunohistochemical features, managment and a review of literature.

CASE REPORT: A 35-year -old male presented to our tertiary care referral centre with a 4 months history of a lesion at right lateral border of the tongue. The lesion was slow growing and painful. Clinical examination revealed a reddish brown mass on right lateral border of tongue measuring approximately $2 \mathrm{x} 2 \mathrm{~cm}$ (Figure 1). It was a well circumscribed firm nodule that was tender. There were no other oropharyngeal lesions or palpable cervical lymph nodes. The patient denied any previous traumatic injury history or betel nut chewing habit. There was no relevant medical or social history.

A punch biopsy was performed and histopathology revealed a malignant mesenchymal neoplasm (Figure 2). On performing immunohistochemistry, tumour cells stained positively with smooth muscle actin (Figure 3), vimentin and desmin. Stains for epithelial marker (CK AE3/AE1), melanoma marker (S100), CD34 and factor VIII were negative. The histopathological features of the specimen in conjunction with the immunohistochemical staining pattern were consistent with leiomyosarcoma.

The chest radiograph was normal and magnetic resonance imaging indicated no disease in the neck. Right hemiglossectomy and supraomohyoid neck dissection was performed under general 
anaesthesia. Histopathological examination showed the peripheral resected margins to be tumour free and the 12 resected lymph nodes were negative for malignancy. The patient was followed up monthly for a year, 3 monthly for the next year and 6 monthly thereafter, with no evidence of recurrent disease and no further treatment in the form of radiotherapy/chemotherapy.

DISCUSSION: Leiomyosarcoma is an exceptionally rare malignant mesenchymal neoplasm in the oral cavity owing to the paucity of smooth muscles in this region. Within the oral cavity, maxilla is the most common site involved followed by the mandible, tongue, cheek and floor of mouth, in descending order ${ }^{17}$.

The cause of leiomyosarcoma remains uncertain, although cases associated with trauma, oestrogen stimulation, ionizing irradiation and the Epstein-Barr virus have been reported ${ }^{22}$. Several theories have been proposed on the origins of primary leiomyosarcoma of the tongue. Since only striated muscle is found in the oral cavity, such tumours probably result from the smooth muscle of the walls of blood vessels or of the circumvallate papillae of the tongue 20 . Other proposed sites of origin are arteriovenous anastomosis and thyroglossal tissues ${ }^{2,5,12}$.

Clinically, leiomyosarcoma often presents as a discrete, painless, slowly enlarging mass that is firmly adherent to surrounding soft tissue ${ }^{21}$. Histologically, the tumour is locally aggressive and highly infiltrating 23 , often leading to local recurrence and haematogenous metastasis to cervical and pulmonary regions ${ }^{24}$. Both histological examination and immunohistochemistry staining are essential for the final diagnosis of oral leiomyosarcoma, as histology alone cannot differentiate between the different mesenchymal tumours. The histological criteria for diagnosis include the presence of nuclear pleomorphism, bizarre cell forms, a pattern of interlacing bundles of smooth muscle cells, and a high rate of mitosis (>5 mitotic figures/high power field $)^{21}$. Immunohistochemical staining of leiomyosarcoma has consistently demonstrated a positive response to smooth muscle actin (SMA), vimentin and desmin. Whereas, a negative response to the S100 protein and the cytokeratins is usually found 2,7 .

Once diagnosed, wide local excision of the tumour with tumour free margins and regional lymph node dissection when required seems the most appropriate treatment that may improve long term survival21. The benefits for treating leiomyosarcoma of the tongue with chemotherapy and radiotherapy remain uncertain and there is insufficient evidence to support their efficacy. Only one case has been reported to date, that was treated with radiotherapy alone, owing to surgically inoperable leiomyosarcoma at the base of the tongue; with 1.5 years follow-up, no local recurrence or distant metastasis was noted ${ }^{7}$. Chemotherapy alone for the treatment of leiomyosarcoma tongue has been reported in only one case in literature, in which owing to lung and multiple soft tissue metastasis, palliative treatment seemed more appropriate. A combination of ifosfamide and doxorubicin was used, following which there was a marked decrease in the primary tongue lesion ${ }^{21}$. Further research is required to determine the efficacy and prognostic benefit of adjuvant therapy in the management of leiomyosarcoma of tongue.

Table I summarizes all the 24 reported cases, including the present case, of primary tongue leiomyosarcoma2-21. Based on these studies, the most appropriate treatment is wide local excision of the tumour with histologically proven tumour-free margins. However, the number of reported cases of primary leiomyosarcoma of the tongue is small, and further research and long term follow-up is 
required to better understand the behaviour, risk factors and predictors of treatment outcome to improve the long term survival of this rare neoplasm.

\section{SUMMARY:}

- Leiomyosarcomas are malignant tumours of smooth muscles and hence, are rare in the head and neck, especially the tongue.

- Diagnosis is confirmed by histological examination and immunohistochemical positivity for vimentin, desmin and smooth muscle actin.

- Wide local excision of the tumour with tumour free margins and regional lymph node dissection when required is the treatment of choice.

- Low reported recurrence rate and survival data suggests a better prognosis, however, further case experience and research is required to better understand this rare neoplasm.

\section{REFERENCES:}

1. Weiss SW, Goldblum JR: Enzinger and Weiss's Soft Tissue Tumors (ed 4). St Louis, Missouri, Mosby, 2001, pp 199-201.

2. Piattelli A, Artese L. Leiomyosarcoma of the tongue: a case report. J Oral Maxillofac Surg. 1995; 53(6):698-701.

3. Yannopoulos K, Stout AP. Smooth muscle tumors in children. Cancer 1962; 15:958-70.

4. O’Day RA, Soule EH, Gores RJ. Soft tissue sarcomas of the oral cavity. Mayo Clin Proc. 1964; 39:169-181.

5. Goldberg MH, Polivy C, Saltzman S. Leiomyosarcoma of the tongue: report of case. J Oral Surg. 1970; 28:608-11.

6. Lack EE. Leiomyosarcomas in childhood: a clinical and pathologic study of 10 cases. Pediatric pathology. 1986; 6:181-97.

7. Aydin H, Dreyer T. Leiomyosarcoma of the base of the tongue treated with radiotherapy: a case report. Eur J Cancer B: Oral Oncol. 1994; 30B(5):351-5.

8. Mayall F, Hickman J, Bulman C, Blewitt R. Leiomyosarcoma of the tongue: a very rare tumor. J Laryngol Otol. 1994; 108(7):617-8.

9. Tandon DA, Fernandes P, Maheshwari A, et al. Leiomyosarcoma of the base of tongue. Indian Journal of Otolaryngology and Head and Neck Surgery. 1996; 48: 235-37.

10. Gorsky M, Epstein JB. Head and Neck and intra-oral soft tissue sarcomas. Oral Oncol. 1998; 34:292-96.

11. Dry SM, Jorgensen JL, Fletcher CD. Leiomyosarcomas of the oral cavity: An unusual topographic subset easily mistaken for non mesenchymal tumours. Histopathology. 2000; 36(3): 210-20.

12. Lo Muzio L, Flavia G, Mignogna MD, Piattelli A: Primary intraoral leiomyosarcoma of the tongue and immunohistochemical study and review of the literature. Oral Oncol. 2000; 36: 519-524.

13. Sakamoto K, Matsuzaka K, Yama M, et al. A case of leiomyosarcoma arising from the tongue. Oral Oncol Extra. 2005; 41:49-52.

14. Kazemian A, Kamian SH, Hoseini MS, et al. Leiomyosarcoma of the tongue: Report of a case. Iran J Radiat Res. 2005; 3(3):143-147. 
15. Yang TL, Chiang CP, Kok SH, et al. Leiomyosarcoma of the tongue- A case report. Clin J Oral Maxillofac Surg. 2006; 17: 109-116.

16. Yang SW, Chen TM, Tsai CY, Lin CY: A peculiar site of leiomyosarcoma: the tongue tip-report of a case. Int J Oral Maxillofac Surg. 2006; 35:469-471.

17. Ethunandan M, Stokes C, Higgins B. Primary oral leiomyosarcoma: a clinico-pathologic study and analysis of prognostic factors. Int J Oral Maxillofac Surg. 2007; 36:409-416.

18. Crossman T, Ward P, Herold J. Leiomyosarcoma of the tongue: a case report. Br J Oral Maxill Surg. 2008; 46:e69-e70.

19. Yan B, Li Y, Pan J, et al. Primary oral leiomyosarcoma: A retrospective clinical analysis of 20 cases. Oral Dis. 2010; 16(2):198-203.

20. Pires CAS, Pires LFS, Paber PA. A primary leiomyosarcoma of the lateral border of the tongue. Oral Surg Oral Med Oral Pathol Oral RadiolEndod. 2010; 109:e31-e33.

21. Ahn JH, Mirza T, Ameerally P. Leiomyosarcoma of the tongue with multiple metastasis: A case report and review of literature. J Oral Maxillofac Surg. 2012 Jul; 70(7):1745-50.

22. Schenberg ME, Slootweg PJ, Koole R: Leiomyosarcoma of the oral cavity. Report of four cases and review of the literature. J Craniomaxillofac Surg. 1993; 21:342-347.

23. Phelan JT, Sherer W, Mesa P. Malignant smooth muscle tumours (leiomyosarcomas) of soft tissue origin. N Eng J Med. 1962; 266:1027-30.

24. Freedman PD, Jones AC, Kerpel SM. Epithelioidleiomyosarcoma of the oral cavity: report of two cases and a review of the literature. J Oral Maxillofac Surg. 1993; 51: 928-32.

\begin{tabular}{|c|c|c|c|c|c|c|c|}
\hline STUDY & YEAR & GENDER & $\begin{array}{c}\text { AGE } \\
\text { (years) }\end{array}$ & SITE & METASTASIS & TREATMENT & $\begin{array}{c}\text { FOLLOW } \\
\text { UP (years) }\end{array}$ \\
\hline $\begin{array}{l}\text { Yannopoulos } \\
\text { and Stout }{ }^{3}\end{array}$ & 1962 & M & $11 \mathrm{mo}$ & Tip of tongue & No & Excision & $4-6$ \\
\hline O'Day et al $^{4}$ & 1964 & $\mathrm{M}$ & 3 & Sublingual & Yes & Excision & 2 , deceased \\
\hline $\mathrm{O}^{\prime}$ Day et $\mathrm{al}^{4}$ & 1964 & $\mathrm{~F}$ & 19 & Sublingual & Yes & $\begin{array}{c}\text { Excision and } \\
\text { neck dissection }\end{array}$ & 11 \\
\hline Goldberg et $\mathrm{al}^{5}$ & 1970 & M & 54 & Sublingual & No & Excision & 1.5 \\
\hline Lack $^{6}$ & 1986 & M & 2.5 & $\begin{array}{l}\text { Base of } \\
\text { tongue }\end{array}$ & No & Excision + CT & 4 \\
\hline $\begin{array}{l}\text { Aydin and } \\
\text { Dreyer }^{7}\end{array}$ & 1994 & M & 70 & $\begin{array}{c}\text { Base and } \\
\text { dorsum of } \\
\text { tongue }\end{array}$ & No & RT & 1.5 \\
\hline Mayall et $\mathrm{al}^{8}$ & 1994 & M & 60 & Tip of tongue & No & Excision & 1 \\
\hline $\begin{array}{c}\text { Piattelli and } \\
\text { Artese }^{2}\end{array}$ & 1995 & $\mathrm{~F}$ & 80 & $\begin{array}{c}\text { Lateral } \\
\text { border tongue }\end{array}$ & No & $\begin{array}{c}\text { Patient rejected } \\
\text { treatment }\end{array}$ & $\mathrm{N} / \mathrm{A}$ \\
\hline Tandon et $\mathrm{al}^{9}$ & 1996 & M & 22 & $\begin{array}{l}\text { Base of } \\
\text { tongue }\end{array}$ & No & Excision & 5 \\
\hline $\begin{array}{l}\text { Gorsky and } \\
\text { Epstein }^{10}\end{array}$ & 1998 & M & 57 & $\begin{array}{c}\text { Lateral } \\
\text { border of } \\
\text { tongue }\end{array}$ & Not recorded & Excision + RT & 4 , deceased \\
\hline
\end{tabular}


CASE REPORT

\begin{tabular}{|c|c|c|c|c|c|c|c|}
\hline Dry et al ${ }^{11}$ & 2000 & $\mathrm{~F}$ & 15 & Not specified & No & Excision + CT & 4 \\
\hline Dry et al ${ }^{11}$ & 2000 & $\mathrm{~F}$ & 88 & $\begin{array}{l}\text { Floor of } \\
\text { mouth }\end{array}$ & Yes & No treatment & Deceased \\
\hline $\begin{array}{l}\text { Lo Muzio et } \\
\qquad \mathrm{al}^{12}\end{array}$ & 2000 & M & 67 & $\begin{array}{c}\text { Lateral } \\
\text { border of } \\
\text { tongue }\end{array}$ & No & Excision & 5 \\
\hline $\begin{array}{c}\text { Sakamoto et } \\
\mathrm{al}^{13}\end{array}$ & 2005 & M & 67 & Tip of tongue & No & Excision & $\begin{array}{c}\text { Not } \\
\text { recorded }\end{array}$ \\
\hline $\begin{array}{c}\text { Kazemian et } \\
\mathrm{al}^{14}\end{array}$ & 2005 & M & 32 & $\begin{array}{l}\text { Lateral } \\
\text { border of } \\
\text { tongue }\end{array}$ & Yes & $\begin{array}{c}\text { Excision + MND } \\
+\mathrm{CT}\end{array}$ & $\begin{array}{c}1.5, \\
\text { deceased }\end{array}$ \\
\hline Yang et al ${ }^{15}$ & 2006 & $\mathrm{~F}$ & 57 & $\begin{array}{c}\text { Lateral } \\
\text { border of } \\
\text { tongue }\end{array}$ & No & Excision + SOND & 3 \\
\hline Yang et al ${ }^{16}$ & 2006 & $\mathrm{~F}$ & 54 & Tip of tongue & No & Excision & 1 \\
\hline $\begin{array}{c}\text { Ethunandan } \\
\text { et }^{17} \text { al }\end{array}$ & 2007 & $\mathrm{~F}$ & 79 & Not specified & No & Excision & 2.5 \\
\hline $\begin{array}{c}\text { Ethunandan et } \\
\text { al }^{17}\end{array}$ & 2007 & $\mathrm{~F}$ & 97 & Not specified & No & Excision & 4.5 \\
\hline $\begin{array}{c}\text { Crossman et } \\
\text { al }^{18}\end{array}$ & 2008 & $\mathrm{~F}$ & 46 & $\begin{array}{c}\text { Lateral } \\
\text { border of } \\
\text { tongue }\end{array}$ & No & Excision & 5 \\
\hline Yan et al ${ }^{19}$ & 2010 & M & 48 & $\begin{array}{c}\text { Floor of } \\
\text { mouth }\end{array}$ & No & Excision + SOND & $\begin{array}{c}1.5, \\
\text { deceased }\end{array}$ \\
\hline Pires et al ${ }^{20}$ & 2010 & M & 55 & $\begin{array}{c}\text { Lateral } \\
\text { border of } \\
\text { tongue }\end{array}$ & No & Excision & 4 \\
\hline Ahn et $\mathrm{al}^{21}$ & 2011 & $\mathrm{~F}$ & 54 & $\begin{array}{c}\text { Lateral } \\
\text { border of } \\
\text { tongue }\end{array}$ & Yes & Palliative CT & $1 \mathrm{mo}$ \\
\hline Present case & 2012 & M & 35 & $\begin{array}{c}\text { Lateral } \\
\text { border of } \\
\text { tongue }\end{array}$ & No & Excision + SOND & 3 \\
\hline
\end{tabular}

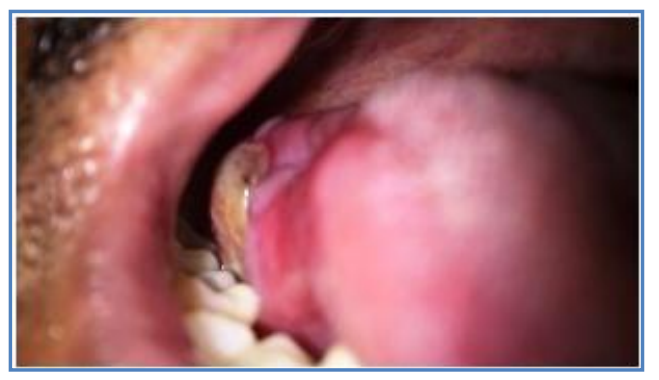

Fig. 1: Clinical photograph of the lesion involving the right lateral border of tongue. 

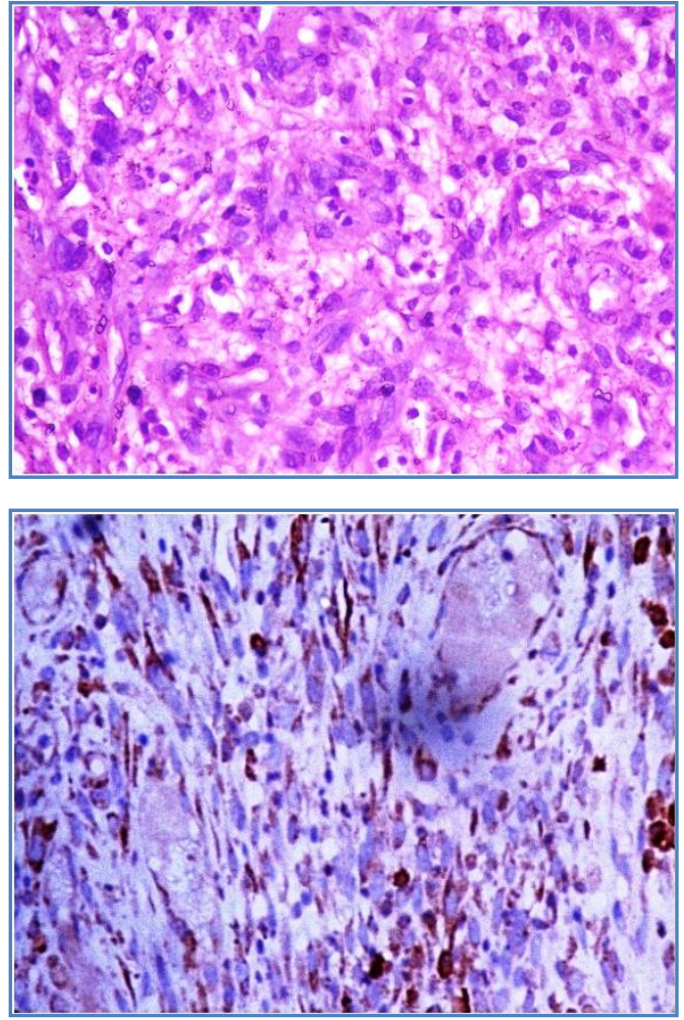

Fig. 2: Photomicrograph of the lesion showing interlacing spindle cell bundles demonstrating cellularpleomorphism and mitosis (H\&E, x40).
Fig. 3:Photomicrograph of the lesion showing diffuse staining with smooth muscle actin (x40).

\section{AUTHORS:}

1. Avani Jain

2. Shashank Nath Singh

3. Pawan Singhal

4. Manprakash Sharma

5. Sunil Samdani

\section{PARTICULARS OF CONTRIBUTORS:}

1. Junior Resident, Department of Otolaryngology and Head and Neck Surgery, Sawai Man Singh Medical College and Hospital, Jaipur, Rajasthan, India.

2. Assistant Professor, Department of Otolaryngology and Head and Neck Surgery, Sawai Man Singh Medical College and Hospital, Jaipur, Rajasthan, India.

3. Associate Professor, Department of Otolaryngology and Head and Neck Surgery, Sawai Man Singh Medical College and Hospital, Jaipur, Rajasthan, India.
4. Professor, Department of Otolaryngology and Head and Neck Surgery, Sawai Man Singh Medical College and Hospital, Jaipur, Rajasthan, India.

5. Department of Otolaryngology and Head and Neck Surgery, Sawai Man Singh Medical College and Hospital, Jaipur, Rajasthan, India.

\section{NAME ADDRESS EMAIL ID OF THE CORRESPONDING AUTHOR:}

Dr.Avani Jain,

Flat No. C-8, Tower 1,

New MotiBagh,

New Delhi - 110023, India.

Email-avanijain87@hotmail.com

Date of Submission: 28/11/2013.

Date of Peer Review: 29/11/2013.

Date of Acceptance: 30/12/2013.

Date of Publishing: 10/01/2014 